\title{
Ascendants That Influence the Adoption of E-government Services among Citizen of Pakistan
}

\author{
Ali Hammad \\ School of public Affairs, University of Science and Technology of China, China \\ E-mail: Alihamad@mail.ustc.edu.cn
}

Intikhab Ahmad

Department of Science \& Technology Communication and Policy

University of Science and Technology of China, China

E-mail: intikhabahmad@mail.ustc.edu.cn

\begin{abstract}
Syed Muhammad Sikander
School of public Affairs, University of Science and Technology of China, China E-mail: sikandar@mail.ustc.edu.cn
\end{abstract}

Md Amjad Hossain Reyad

School of public Affairs, University of Science and Technology of China, China E-mail: reyad@mail.ustc.edu.cn

Syed Mazahir Kazmi (Corresponding author)

School of public Affairs, University of Science and Technology of China, China E-mail: mazahir@mail.ustc.edu.cn

Received: April 3, 2019 Accepted: April 19, 2019 Published: May 7, 2019

doi:10.5296/ber.v9i2.14756 URL: https://doi.org/10.5296/ber.v9i2.14756 


\section{Abstract}

In this research study, the author seeks to discover the predecessors of e-government services adoption among the citizen of Pakistan. To study the e-government adoption, researcher integrates extended TAM and theory of planned behaviour. Cross-sectional research technique was used and in total data was collected from 240 citizens of Pakistan. Results depict that facilitating conditions, performance expectancy, effort expectancy positively impact the citizen attitude towards adoption of e-government facilities. As well as, facilitating conditions as a positive impact on society and individual computer self-efficacy which helps in building citizen attitude.

Furthermore, the researcher studies the impact of government trust as a moderator to test the relationship between attitude and adoption of e-government services. Results show that government trust dampens down the relationship between attitude and e-government adoption. To the conclude results SEM technique was used using AMOS-21.

Keywords: Performance expectancy, Effort expectancy, Facilitating condition, Trust in government

\section{Introduction}

The e-Government is the usage of IT tools and applications to increase liability and pellucidity of government departments by refining public service. Also, e-government gives citizen access to information regarding services provided by the government (Panagiotopoulos, Al-Debei, Fitzgerald, \& Elliman, 2012). E-government enhances governance which helps improve accountability and transparency. Benefits embedded in e-government are the main reasons which encourage governments to participate in e-services scheme developments (Chatfield \& Alanazi, 2015; Chen, Jubilado, Capistrano, \& Yen, 2015). E-government introduces the new IT system to automatically process the tradition of public services or add new channels to online. Therefore, it can help the government function to improve and create new values for businesses and citizens. In order to achieve these goals citizen involvement, participation and engagement are necessary for e-government services. Nevertheless, regardless of significant efforts by the government to implement e-services, governments face challenges due to the low-level e-services provided to citizens (Rana \& Dwivedi, 2015; Batara, Nurmandi, Warsito, \& Pribadi, 2017). The immediate problems require the urgent attention of scientists since the e-government success mainly be governed by acceptance and use of its services by citizens(Carter \& Weerakkody, 2008). The importance and understanding of elements that affect the acceptance of citizens towards e-services by the government. Although technology-oriented users widely considered in environments such as e-commerce and the Internet (Beldad, Jong, \& Steehouder, 2011), these users are relatively less research in e-government services(Gupta, S. Dasgupta, \& Gupta, 2008). Use of software and information technology in public and private organizations is needed so that citizens voluntarily and socially use e-services which assist the government in the implementation and execution of e-services in the country.

Chaotic policies, such as a change in policies, political leadership, and cuts in budget cuts are 
the factor which helps the government to retrieve information. E-government services issues are analysed not only from the technological viewpoint but need to analysed broadly by integrating political, social and cultural perspectives in order to understand and develop knowledge (Carter, Shaupp, Hobbs, \& Campbell, 2012). In the absence of a clear and consistent understanding of the uses and benefits of e-government services, people will be reluctant to use e-services. As well the government will not be able to make strategic decisions which increase acceptance and use of e-services (Ahmad, Markkula, \& Oivo, 2012). Previous research primarily focuses on the execution of e-government services in developed countries.

For this reason, less attention has paid by researchers in analysing the acceptance, execution, and use of e-government services in developing countries, especially in Asia countries. It is essential to study developing countries because of their social and cognitive characteristics which including Asian countries, which are very different from developed Western countries (Osmani, 2015). These differences, the factors affecting the Acceptance of technology by people in Asian countries are utterly different from industrialized and well-developed countries.

\section{E-adoption in Pakistan}

In Pakistan, a particular unit was established named as Electronic Government Directorate, under the administration of the ministry of science and technology. The purpose of this unit is to provide technical and managerial guidelines to the ministry for the execution of e-government services in the country. National Electronic Government Directorate present five years plan in 2005, which propose and design standards for the execution of e-government services and applications for citizens. The plan presented by the unit is to enhance awareness and recognition of e-government services among citizens. According to Shah, Khan, \& Khalil (2011)to report the main objective of e-government initiation is Pakistan is to increase transparency, efficiency, and accountability also, the delivery the cost-effective and reliable services to people who assist them in making a decision. In developing countries, low-level adoption of e-government services among citizen is due to the ignorance of the government towards citizen needs and requirements. It is the need of the time that governments should focus on developing instruments and determine influential factors which assist them in attracting potential and encourage them to use e-government services.

\subsection{Purpose}

E-government services adoption among citizen is key for the effective implementation of e-government plans (Liu, et al., 2014). Rehman, Mariam, Esichaikul, \& Vatcharaporn (2011) urged that there is a need to study e-government services and transfer of such ideas to Asia regions. Reddick, (2005) explains the flow of the first government issues from a wider perspective is an indication of essential points when describing and selling public services (for example, a country, a state, a state, or a state). By today, the factors affecting and influencing the acceptance and implementation of government agencies for e-government services (Norris \& Reddick, 2013). Examples include systematic planning, IT health and 
skilled workers.

On the other hand, the second threat of government issues is to welcomed from the consumer's demands for public participation (for example, citizens). Some experts use some talking about the economic work of residents of analysis by the government. However, when there are research is on the need for e-government acceptance, there is little to know about the cause and use of public e-services.

Therefore, the purpose of this research paper is to investigate intrinsic and extrinsic factors that influence the adoption of the citizen towards e-government service and to provide the solution to problems faced by the government while launching and execution of e-government services. To examine the e-government adoption; extended Technology acceptance model (TAM) using facilitate condition, performance expectancy and effort expectancy is used and Theory of planned behaviour (TPB) social influence, computer self-efficacy is incorporated to measure attitude and intention of youth towards e-government(Davis, 1989; Ajzen \& Fishbein, 1980). Then trust on e-government is used as a moderator which measure the relationship between attitude and intention of the youth of developing countries like Pakistan towards e-government services.

\subsection{Theoretical Framework}

Technology Acceptance Model (TAM) was presented by (Davis, 1989), and researchers used this theory to study the technology acceptance. TAM is originated from the Theory of Reasoned Action (TRA), which validates the transformational behaviour of the citizen towards technology adoption (Ajzen \& Fishbein, 1980). Two basic and essential constructs are used to measure the individual behaviour towards technology that is perceived ease of use/effort expectancy and perceived usefulness/performance expectancy. To come up with the solution that people adopt e-government services, extended TAM is used with new construct: facilitating condition that can be explained as resources and support that is given by the environment in shaping up particular behaviour value. In this research study, facilitating conditions, expected expectancy and effort expectancy factors are used to examine technology impacts on computer self-efficacy and society that impacts and develop the attitude of the citizen towards the adoption of e-government services. To acutely understand the phenomena theory of planned behaviour and technology acceptance is integrated.

Zulfiqar, Sarwar, Aziz, Chandia, \& Khan(2018), Benbasat \& Barki (2007)and Chen (2016) used TAM and TPB integrated model to investigate the influence of technology used on the attitude and adoption of technology. In prior studies, researchers use (TAM) to forecast and predict the intent of the individual to adopt the technology(Wang, Rau, \& Salvendy, 2011). Benbasat \& Barki (2007) and Chen (2016)used an extended TAM model in developing countries to investigate the intention of the user to adopt the latest technology. However, from the previous literature review and researches, the researcher concluded that no research adopted extended TAM and integrate it with the theory of planned behaviour to investigate the intention of the citizen towards e-government services. 


\subsection{Performance Expectancy and Effort Expectancy}

Effort expectancy is the degree to which the user finds the ICT system easy to operate (Venkatesh, Thong, \& Xu, 2012). According to Carter \& Bélanger, (2005) attitude and intention of the citizen will enhance if they perceive e-services provided by government-friendly and easy to use. Effort expectancy is an important determinant and influential interpreter of e-government adoption. In general, individual is more inclined to adopt technology that they find easy to understand, in a friendly way and use.

Performance expectancy referred to as the degree to which technology enables the user to improve its capabilities to accomplish and complete their jobs efficiently. Performance expectancy is an important determinant that assists in predicting the attitude and intention of the user towards e-services adoption. According to Alryalat, Rana, \& Dwivedi (2015) performance expectancy is the extent to which people believe that ICT system assists the user in shaping their attitude and behaviour and also assist in improving their job performance.

\subsection{Facilitating Condition}

Facilitating condition is the perception of individuals about the resources and support that is given by the environment in shaping up particular behaviour (Rana, Williams, Dwivedi, \& Williams, 2011). In the context of e-government service adoption, facilitating conditions are the grade to which citizen perceives that sufficient resources provided by the government which assists and facilitates them in using e-services provided by the government. According to Venkatesh, Thong, \& Xu (2012)facilitating facility has a significant effect on the behavioural intention of the citizen towards adopting e-services. Kurfali, Arifoglu, Tokdemir, $\&$ Pacin maintained the point of view that degree to which respondents believe that infrastructure and facilitates are supporting new ICT needs to be provided by the government are sufficient that may impact their attitude and intention towards the adoption of e-government services.

\subsection{Attitude}

Kinicki \& Kreitner (2009)define attitude as the tendency of an individual to express his/her thoughts in favour and disfavour while assessing a specific situation. Harjer \& Habib (2013) responsive reaction of an individual after having experience with ICT (Zimmerman, 2008)attitude would influence the individual intentional behavior towards ICT adoption. Expectations of individuals while indulging with e-government services can either positive or negative depends upon the performance expectancy, effort expectancy and facility condition provided by the government. This attitude can consequently be transformed into an intention (Ajzen \& Fishbein, 1980).

\subsection{Social Influence}

Cialdini et al. (1991)social influence is the faith that society will admire specific behaviour for a while using a given technology. Social influence is people's opinion from whom the individual is inspired to behave when interacting with technology (Elster, 1989). Ajzen \& Driver (1991); Zhao et al. referred to social influence is the referents that pressurized and 
influencer in making technology-related decision i-e parents, friends, teachers. A social influencer is the one who motivates, encourage and approve and inclined individual attitude towards technology.

\section{Computer Self-Efficacy}

Computer Self-Efficacy is the capability of an individual to practice computer technology and perform duties and task (Solesvick, 2012). (Icek Ajzen 2002) stated that the self-efficacy is that individuals ability to control their behaviours or actions (Rotter, 1966)\& computer self-efficacy as the predecessor of intention to adopt e-government services, if the individual is self-motivated and has a strong intention towards e-government services. Computer self-efficacy is that an individual can utilize cognitive resources and have the motivation ability to access e-government. In other words, computer self-efficacy is the strength of an individual's belief that he/she is capable of performing all the duties and task using computer (Chen, Greene, \& Crick., 1998). Computer self-efficacy is the predecessor of intention, and it has been examining that computer self-efficacy influence's intention-behavior of the individual to adopt e-government services.

\subsection{Moderator: Trust in Government}

Trust on e-government is "the use of government technology to transform the relationship with people, business firms and other government agencies" (World Bank Group, 2007). It can also be defined as "the ability of the government to ensure the security of its people's data in online transactions." Therefore it is essential to have trust in government regulation and policies to ensure the success of new technology like e-government services because if the government is credible and competent, then it is likely that people will adopt its services (Adel Al Khattab1, 2014). Tan and Theon (2001), argues that there is a link between trust and e-government. Trust acts as a medium that encourages people to trust in government agencies providing services, but it is the belief that hinges upon that government agencies if they are capable of providing those services without any security threat and sensitive information leaked ensuring the protection of its citizens (Lemuria Carter , 2008). In the last decade, the modernization of the government institutions and the vast potential of information and communication technology can play a significant part in forming trust among citizen towards e-government services. As new topics such as electronic administration, democracy and e-government emerged, as an important tool for the improvement of public sectors and to create the impact on the environment to transform the mind-set of people towards government developments processes(Sofia Elena Colesca , 2009).

Another study on e-government and trust reveals that people's trust in government reduces the risk of using e-government services respectively (Beldard, jong, \& Streehouder, 2011). When a person trusts in government, he expects the same honour and trust of the government. Thus the level of trust defines government credibility, and there is a large amount of literature on online trust, the impact of felt trust and adoption of electronic business or government services in particular and one should investigate those factors to improve their service so that they can improve (Dashti, Benbasat, \& Burton-Jones, 2010). Researchers believe that trust in the internet and the government are two of the most significant variables that impact people's 
aims to use e-government services (Esichaikul, 2012).

\subsection{Research Context}

Pakistan is a developing the country and is working for the development of e-government services since 2002. The aim and objective of the government are to enhance the efficiency and effectiveness of the public administrative and legislative institutes. Government is providing funds to institutes to encompass e-government services not only at national as well as at the provincial level. However, due to poor ICT infrastructure, computer facilities, Pakistan is facing numerous threats and problems and challenges in this sector. Due to weak interconnectivity between government institutes and educational system, people are unwilling to consume e-government services. However, due to the full availability of internet services at significant cities allow the user to adopt e-services.

The aim and objective of this study are to study the factor affecting citizen adoption towards e-government services. As most of the government institute is encouraging citizen to apt e-government services to get access to information and knowledge using e-services like applying for a new passport, visa application, online payment for renewal of passport, using national testing services for hiring of new employees but still, the citizen is facing a significant number of challenges.

\subsection{Research methodology}

Quantitative method approach is used in this research paper and data is collected from respondents; self-administrated questionnaire and online survey techniques were used to measure the factor affecting acceptance of e-government services. A closed-ended questionnaire was used in order to have a better and clear understanding of result and interpretation. For this research paper, secure and cost-effective data collection methodology was used to collect data from the youth of Pakistan. These techniques included data online survey software i-e survey monkey.

Furthermore, questionnaires were circulated through mobile application messengers like WHATSAPP and WECHAT. This questionnaire includes facilitating condition, performance expectancy, effort expectancy, computer self-efficacy and adoption of e-government services. The current study is apprehensive, and it examines the factors affecting the citizen attitude and their adoption towards e-government services.

A pilot study was run before collecting data from respondents. The main purpose of the pilot study was to refine the questionnaire so that respondents can easily understand the questionnaire and also assist the researcher in solving problems like coding and decoding of data collected. After designing the questionnaire, a pilot study was conducted, and questionnaires were dispersed among youth who are the primary user of e-government services. Respondents were requested to give feedback regarding questionnaire wording, phrasing and format. After getting feedback changes were made so that youth can easily understand the concept and phrases of the questionnaire. It increases the reliability and validity of the questionnaire. 


\subsection{Measures}

5-point Likert scales were used to measure the responses of the respondent, ordered as 1 , strongly disagree, 3 , neutral, and 5, strongly agree. The questionnaire was modified from with slight adjustments of words in order to confirm the validity of constructs. Facility condition (Lallmahomed, Lallmahomed, \& Lallmahomed, 2017) and attitude (Zulfiqar, Sarwar, Aziz, Chandia, \& Khan, 2018; Kuo, Wub, \& Deng, 2009), Effort Expectancy, performance expectancy (Miloševic, Zivkovic, Manasijevic, \& Nikolic, 2015; Lallmahomed, Lallmahomed, \& Lallmahomed, 2017); attitude towards e-government services (Al-Shafi \& Weerakkody, 2009); Trust on government(Meuter, Ostrom, Bitner, \& Roundtree, 2003). Demographic information of the respondents includes age, gender, education, and experience with e-government services are shown in Table 1.

Table 1. Demographics Information

\begin{tabular}{|l|l|l|}
\hline Demographic information & Frequency & Percentage \\
\hline Age & & \\
$18-22$ & 91 & 36.4 \\
$23-27$ & 98 & 39.2 \\
$28-32$ & 54 & 21.6 \\
$33-40$ & 7 & 2.8 \\
\hline Gender & & \\
Male & 135 & 54 \\
Female & 115 & 46 \\
\hline Education & & \\
High School & 39 & 15.7 \\
Graduate & 19 & 7.80 \\
Post-graduate & 119 & 47.50 \\
Ph.D. & 73 & 29 \\
\hline
\end{tabular}

\subsection{Data Analysis}

Structural Equation Modelling (SEM) employed using AMOS version 21 aimed at establishing a model and data analysis. AMOS is important structural equation model software that helps researchers to support their research by using multivariate analysis methods including factor analysis, correlation, and variance and regression analysis (Hair, Black, Basin, \& Anderson, 2010; Pituch \& Stevens, 2016). The quantitative analysis method is used to understand the relationship between variables. Items used to test hypotheses were first to validate by using factor loading and Cronbach alpha tests. Then discriminant validate test was conducted to further validate the data before moving towards testing hypotheses using multiple regression analysis using structural equation method. Multiple regression analysis using SEM authorizes researchers to classify incremental and control variables that explain the observed variable to test hypotheses.

A three-step approach was used to analyse the statistical data. In the first step, EFA was done to measure the appropriateness of data for factor loadings and factor reduction. Second step Confirmatory factor analysis was done to verify the validity and reliability of constructs. Third step SEM, executed to analyse measurement and structural model which depicts that observed variables are suitable for further analysis. 


\section{Macrothink}

Business and Economic Research

ISSN 2162-4860

2019, Vol. 9, No. 2

Before testing measurement and structural model; EFA was executed to measure the convergent validity of the constructs which can be examined by performing factor loading, Composite reliability (CR), Cronbach Alpha and Average Variance Extracted (AVE) values test. Benchmark values of factor loadings are 0.5, Cronbach Alpha is 0.6, AVE is 0.5 and CR are 0.7(Hair, Anderson, Tatham, \& Black, 1998). As shown in Table 2 of Factor Loadings, Cronbach Alpha, CR values are above 0.7, and AVE values for all constructs are above 0.5. Hence, results showed good convergent validity and valid measure.

Table 2. Reliability and confirmatory analysis

\begin{tabular}{|c|c|c|c|c|c|}
\hline \multicolumn{6}{|c|}{ Reliability and confirmatory analysis } \\
\hline Constructs & Items & Loadings & Cronbach Alpha & $\mathrm{CR}$ & AVE \\
\hline \multirow[t]{3}{*}{ Attitude } & AT 1 & .856 & .885 & 0.886 & 0.722 \\
\hline & AT 2 & .801 & & & \\
\hline & AT 3 & .823 & & & \\
\hline \multirow[t]{3}{*}{ Performance Expectancy } & PRE 1 & .844 & .789 & 0.796 & 0.568 \\
\hline & PRE 2 & .760 & & & \\
\hline & PRE 3 & .791 & & & \\
\hline \multirow[t]{4}{*}{ Facilitate condition } & PVM1 & .900 & 0.932 & 0.933 & 0.776 \\
\hline & PVM2 & .861 & & & \\
\hline & PVM3 & .866 & & & \\
\hline & PVM4 & .885 & & & \\
\hline \multirow[t]{3}{*}{ Government trust } & TA1 & .815 & 0.794 & 0.795 & 0.565 \\
\hline & TA2 & .768 & & & \\
\hline & TA3 & .733 & & & \\
\hline \multirow[t]{3}{*}{ E-government Adoption } & $\mathrm{I} 1$ & .805 & 0.823 & 0.825 & 0.612 \\
\hline & $\mathrm{I} 2$ & .762 & & & \\
\hline & $\mathrm{I} 3$ & .794 & & & \\
\hline \multirow[t]{4}{*}{ Effort Expectancy } & EF1 & .761 & .804 & 0.807 & 0.512 \\
\hline & $\mathrm{EF} 2$ & .826 & & & \\
\hline & EF3 & .771 & & & \\
\hline & EF4 & .801 & & & \\
\hline \multirow[t]{3}{*}{ Social Influence } & ESE1 & .772 & 0.778 & 0.784 & 0.554 \\
\hline & ESE2 & .827 & & & \\
\hline & ESE3 & .720 & & & \\
\hline \multirow[t]{4}{*}{ Computer Self-efficacy } & SF1 & .863 & 0.809 & 0.890 & 0.619 \\
\hline & SF2 & .828 & & & \\
\hline & SF3 & .832 & & & \\
\hline & SF4 & .821 & & & \\
\hline
\end{tabular}

Discriminate validity test was conducted to ensure the validity of data, for this researcher compares the correlation of all values with the calculated AVE square root values of constructs. If calculated AVE square root values stand greater than the calculated constructs correlation, then results depict that good discriminate validity. Results shown in Table 3 
describes good discriminate validity.

Table 3. Mean, standard deviation, Correlation and the square root of AVE

\begin{tabular}{|l|l|l|l|l|l|l|l|l|l|}
\hline & Construct & $\mathrm{M}(\mathrm{SD})$ & 1 & 2 & 3 & 4 & 5 & 6 & 7 \\
\hline 1 & Performance Expectancy & $4.36(1.22)$ & $\mathbf{0 . 7 5 1}$ & & & & & & \\
\hline 2 & Facilitate condition & $4.62(1.25)$ & 0.181 & $\mathbf{0 . 8 1 8}$ & & & & & \\
\hline 3 & Effort Expectancy & $5.15(1.49)$ & 0.087 & 0.060 & $\mathbf{0 . 7 9 2}$ & & & & \\
\hline 4 & Attitude & $4.43(1.01)$ & 0.158 & 0.098 & -0.004 & $\mathbf{0 . 7 7 0}$ & & & \\
\hline 5 & E-government Adoption & $4.69(1.29)$ & 0.474 & 0.300 & -0.023 & 0.300 & $\mathbf{0 . 8 4 6}$ & & \\
\hline 6 & Government Trust & $4.46(1.20)$ & 0.412 & 0.430 & 0.020 & 0.007 & 0.458 & $\mathbf{0 . 7 7 1}$ & \\
\hline 7 & Social Influence & $4.26(1.45)$ & 0.368 & 0.241 & -0.011 & 0.146 & 0.500 & 0.471 & $\mathbf{0 . 7 4 1}$ \\
\hline 8 & Computer Self-efficacy & $4.79(1.16)$ & 0.389 & 0.435 & 0.082 & 0.150 & 0.430 & 0.420 & 0.531 \\
\hline
\end{tabular}

\section{Results}

According to Anderson and Gerbing, SEM is two steps analysis to measure the hypothesized model results shown in Figure 1. In the first phase, confirmatory factor analysis (CFA) was executed to test the measurement model, and in the second phase structural model using SEM was used to test the proposed model fit indices. SEM is a useful technique that can validate research results. To estimate the fitness of the model, researchers examine fitness indices like chi-square, Tucker-Lewis Index (TLI), Comparative Fit Index (CFI), Normative fit Index (NFI) and Root mean square error of approximation (RMSEA). According to $\mathrm{Hu} \&$ Bentler (1999), the accepted value for chi-square should be less than 5.0 depending on the sample size. Value of RMSEA less than 0.07 , it is considered to have good fitness indices. According to Arbuckle, CFI and TLI values should be above 0.90 whereas NFI values should be equal to or above 0.95

\subsection{Measurement Model Analysis}

According to above define benchmark values of indices, it was found that values of chi-square 1.803, TLI .946, IFI .955, CFI .954, NFI .904, and RMSEA. 053 which shows the goodness-of-fit model and results provided the evidence for further examination of the structural model.

\subsection{Structural model Analysis}

Structural model indices indicate that values of chi-square 2.521, TLI 0.882, IFI 0.941, CFI 0.939, NFI 0.906 and RMSEA 0.065 which shows goodness-of-fit model. 


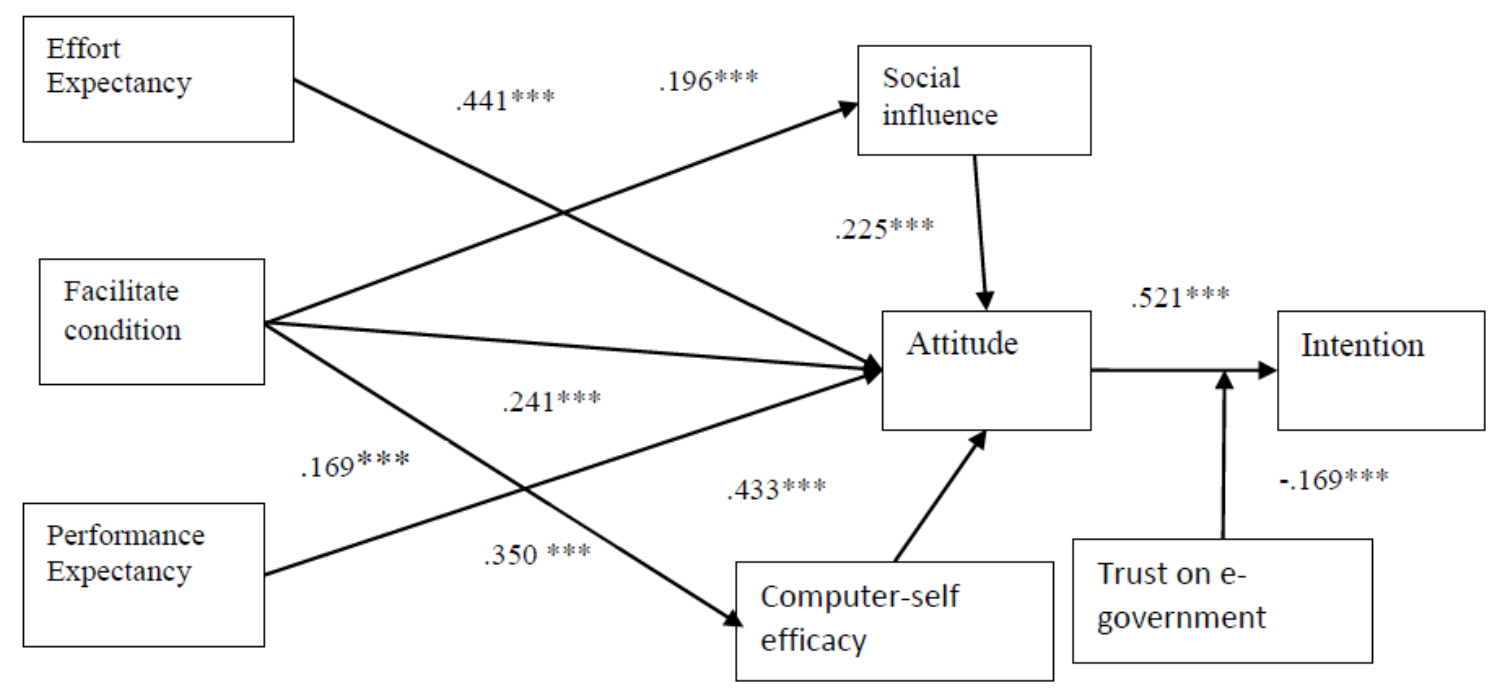

Figure 1. Results of Structural Modeling with Moderation

\begin{tabular}{|l|l|l|}
\hline Hypotheses & Coefficient & Results \\
\hline Effort Expectancy $\rightarrow$ Attitude & $.441^{* * *}$ & Supported \\
\hline Facilitate condition $\rightarrow$ social influence & $.196^{* * *}$ & Supported \\
\hline Facilitate condition $\rightarrow$ computer self-efficacy & $.350^{* * *}$ & Supported \\
\hline Facilitate condition $\rightarrow$ Attitude & $.241^{* * *}$ & Supported \\
\hline Performace Expectancy $\rightarrow$ Attitude & $.350^{* * *}$ & Supported \\
\hline Social influence $\rightarrow$ Attitud & $.225^{* * *}$ & Supported \\
\hline Computer Self-efficacy $\rightarrow$ Attitude & $.433^{* * *}$ & Supported \\
\hline Attitude $\rightarrow$ Intention to adopt e-government & $.521^{* * *}$ & Supported \\
\hline
\end{tabular}

\section{Discussion}

The outcome of the statistical analysis showed that effort expectancy, facilitating condition and performance expectancy significantly impacts its relationship with attitude $(\beta=.441$, $\mathrm{p}<.001),(\beta=.241$,$) and (\beta=.350, \mathrm{p}<.001)$ respectively. Whereas, facilitate condition also have a significant relationship with social influence and computer self-efficacy $(\beta=.196, p<.01)$ and $(\beta=.169, p<.001)$ respectively. Social influence has a positive impact on the attitude of the citizen towards e-government services $(\beta=.225, \mathrm{p}<.001)$ and computer self-efficacy has a positive impact on the attitude of the citizen $(\beta=.433, \mathrm{p}<.01)$. The attitude of the citizen towards the adoption of e-government services is positive with $(\beta=.521, \mathrm{p}<.001)$.

\subsection{Hierarchical Multiple Regression Analysis}

Hierarchical multiple regression results summarize in Table 4. Figure 2 represents the plot that suggests that government trust has an impact on the relationship between attitudes and adoption of e-government services, outcome directs that it dampen down the relationship between attitudes and adoption, due to the presence of government trust.

Table 4. Hierarchical Multiple Regression Analysis

\begin{tabular}{|l|l|l|l|}
\hline Variables & Model 1 & Model 2 & Model 3 \\
\hline
\end{tabular}




\begin{tabular}{|l|l|l|l|}
\hline Age & $.541 * * *$ & $.369 * * *$ & $.332 * * *$ \\
\hline Gender & -.069 & -.021 & -.018 \\
\hline Education & .39 & .019 & .032 \\
\hline Attitude & & $.109 * * *$ & $.159 * * *$ \\
\hline Government trust & & & $.175^{* * *}$ \\
\hline Attitude X government trust & & & $-.169 * * *$ \\
\hline$R^{2}$ & .453 & .538 & .589 \\
\hline $\mathrm{F}$ & $61.84 * * *$ & $59.05^{* * *}$ & $55.76^{* * *}$ \\
\hline
\end{tabular}

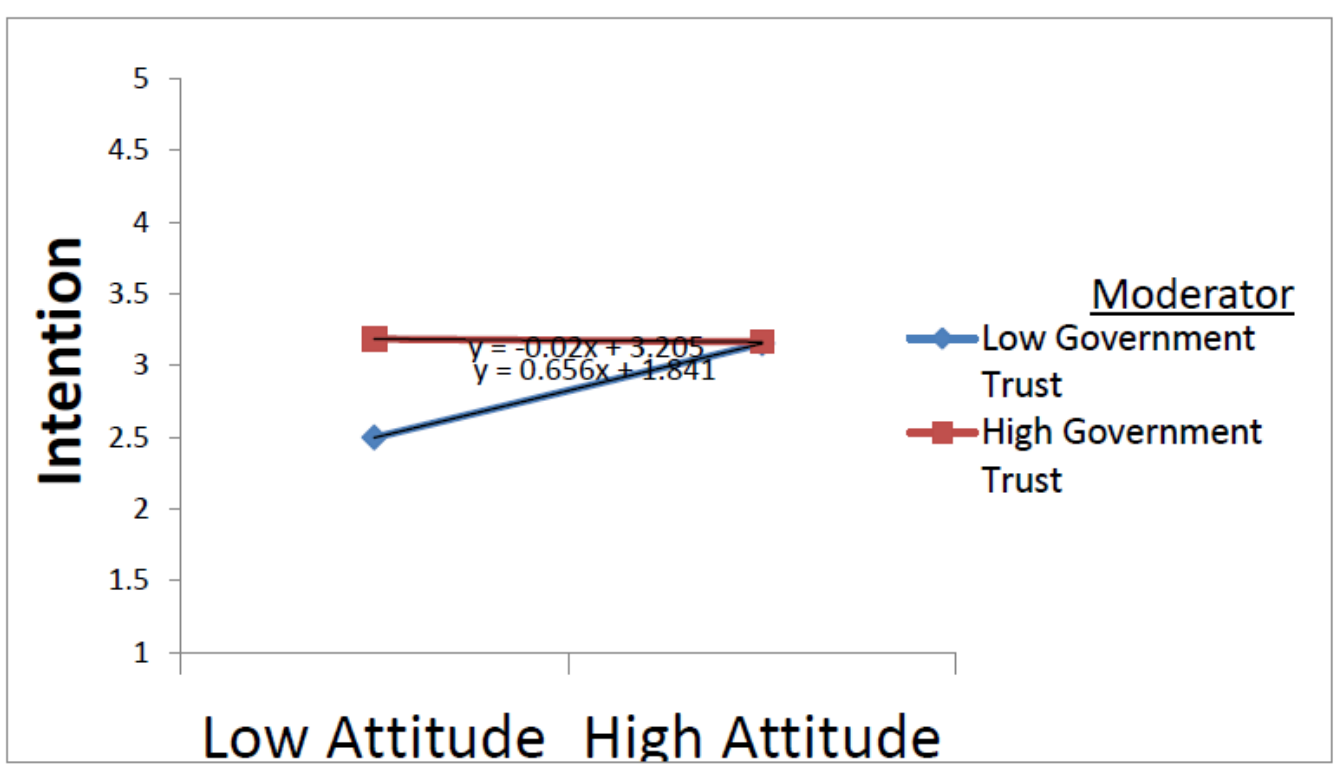

Figure 2. Moderating Effect of Government Trust on Attitude and intention relationship

The determination behind this study is to review determinants that influence Pakistani's citizen e-government services adoption. For this, the author uses an integrated model to study e-government services adoption among the citizen of Pakistan. The factors which researchers used to measure the attitude and intention of the citizen are performance expectancy, facilitating condition, effort expectancy, computer self-efficacy, and social influence. The above study literature depicts that in developing countries like Pakistan there is less adoption of e-government services among citizen because of less facilitating conditions and lack of knowledge about the services. Results depict that facilitating condition an important factor that influence of e-government services adoption. Facilitating conditions exhibit that it significantly affect the behavioural intention of the citizen. Other than awareness about the technology, facilitating conditions, provided by the government can be defined as facilitation and easy access to ICT. Facilitate conditions include the infrastructure and awareness of services the citizen of Pakistan. Awareness can be created by introducing computer services related to subjects in educational subjects plus through advertisements and awareness programs. User manual in written and audio in different languages should be available on websites that citizen can understand the website. Plus 24 hours' online chats which let the 
citizens communicate with experts to get information regarding e-government services of Pakistan.

Results show that performance expectancy emphases on the effectiveness and utility of e-government services. It was witnessed that citizen's attitude access e-government services if they considered them to be beneficial and constructive. Government organizations need to focus on public campaigns that emphasize the use of e-government services and how a citizen can be benefited through e-services. Outcomes of the research depict that designers and developers of e-government websites should make it easy and user-friendly. Effort expectancy is among the essential factor which depicts the citizen attitude and intention to adopt e-services. Social influence which include friends, family, and colleagues that motivate and influence citizen's attitude and intention towards e-government services. Government organizations should encourage their staffs and workers to endorse e-government services at their networks as this inspire and motivate others to use services(Lallmahomed, Lallmahomed, \& Lallmahomed, 2017). Governments should use today's most influential and powerful tool that is social media to stimulate e-government services.

Pakistan is a developing country, and there is a need to implement policies and device strategies that emphasize e-government services benefits. E-services is at an early stage; the government of Pakistan needs to understand the factors that assist them in improving and developing user-friendly and useful services for citizens. On the other, trust in government is also a key determinant which assists a citizen in making adoption decision, as Pakistan is a developing the country as the policies are not long term. There are unstable governments and economic situation which leads to short-term policies. Due to the reason citizen does not trust governmental institutes and they are reluctant to use e-services provided by the government. Tan and Theon (2001) argues the link between trust and e-government where trust acts as a medium that encourages people to trust in government agencies providing services, but it is the belief that hinges upon that government agencies if they are capable of providing those services without any security threat and sensitive information leaked ensuring the protection of its citizens (Lemuria Carter, 2008).

In the last decade, the modernization of government institutions and the vast potential of information and communication technology play a vibrant role in establishing the trust of people towards e-government processes. As new topics such as e-administration, e-democracy, and e-government emerged, they have become an essential tool for the improvement of public sectors and to create the impact on the environment to transform the mind-set of people towards government developments processes(Sofia Elena Colesca , 2009). Colesca argues that trust in technology and propensity are important factors for e-government services adoption whereas Alsaghiar in his study used the components of trust disposition and institution-based trust in this context. Some scholars investigated other components of trust like personality, cognition, institutional or concept that influences the trust in e-government. However, with the dynamic research on this topic, it has been recognized that observing trust as various components and categories rather than a single component is an advancement in the research in the trust and e-government research(Cigdem Akkaya, 2011). Lee and Levy further argue the advantages of e-government services like timeliness, responsiveness and 
cost efficient and also in keeping the citizens up to date with the laws, rules, and regulations with services and also increases the degree and quality of people participation in government policies (Levy, 2014).

E-government and trust reveal that people's trust in government reduces the risk of using e-government services respectively. When a person trusts in government, he expects the same honour and trust of the government. Thus the level of trust defines government credibility, and there is a large amount of literature on online trust, the impact of felt trust and adoption of electronic business or government services in particular and one should investigate those factors to improve their service so that they can improve (Dashti, Benbasat, \& Burton-Jones, 2010). However, as the trust is a very broad term and involves different categories of components, there is still more research needed to gain a clearer understanding of the relationship between trust and e-government service adoption and also to understand how cultural differences may have an impact on trust on e-government. Moreover, it has been found that e-government services improve the perception and attitudes of people towards government performance, and also it helps to decrease corruption and helps to increase trust in public institutions (Celene Navarrete , 2010). Therefore, the government should take serious steps towards e-government to build peoples trust in them.

\section{References}

Aarino, G. A. (2015). Rebuilding government trust in public administrations thruough e-government actions. Research on investigating the marketing, 11 .

Adel, A. K., Al-Shalabi, H., Al-Rawad, M., Al-Khattab, K., \& Hamad, F. (2014). The Effect of Trust and Risk Perception on Citizen's Intention to Adopt and Use E-Government Services in Jordan. Journal of Service Science and Management, 12.

Ahmad, M. O., Markkula, J., \& Oivo, M. (2012). Factors Influencing the Adoption of Egovernment Services in Pakistan. European, Mediterranean \& Middle Eastern Conference on Information Systems.

Ajzen, I., \& Fishbein, M. (1980). Understanding Attitudes and Predicting Social Behaviour. NJ: Prentice-Hall, Englewood Cliffs.

Alryalat, M., Rana, N., \& Dwivedi, Y. (2015). Citizen's adoption of an e-government system: validatingthe extendedtheoryof reasonedaction. International Journal Electr Government Research, 11(4), 1-23. https://doi.org/10.4018/IJEGR.2015100101

Al-Shafi, S., \& Weerakkody, V. (2009). Understanding citizens' behavioural intention in the adoption of e-government services in the state of Qatar. 17th European Conference on Information Systems, European Conference on Information system, (pp. 1618-162).

Anderson, J. C., \& Gerbing, D. W. (1988). Structural Equation Modeling in Practice: A Review and Recommended Two-Step Approach. Psychological Bulletin, 103(3), 411-423. https://doi.org/10.1037/0033-2909.103.3.411

Arbuckle, J. (2003). Amos 5.0 Update to the AMOS User's Guide. Cicago: Small Waters 
Corp.

Batara, E., Nurmandi, A., Warsito, T., \& Pribadi, U. (2017). Are government employees adopting local e-government transformation? The need for having the right attitude, facilitating conditions and performance expectations. Transforming Government: People, Process and Policy. https://doi.org/10.1108/TG-09-2017-0056

Baumeister, R., \& Leary, M. (1995). The need to belong: desire for interpersonal attachments as a fundamental human motivation. Psychological Bulletin.

https://doi.org/10.1037/0033-2909.117.3.497

Becker, S., \& Woessmann, L. (2009). Was weber wrong? A human capital theory of protestant economic history. Q. Journal Economic, 124(2), 531-596.

https://doi.org/10.1162/qjec.2009.124.2.531

Bélanger, F., \& Carter, L. (2008). Trust and risk in e-government adoption. . Journal of Strategic. Information System, 17(2), 65-176. https://doi.org/10.1016/j.jsis.2007.12.002

Beldad, A., Jong, M. D., \& Steehouder, M. (2011). I trust not therefore it must be risky: Determinants of the perceived risks of disclosing personal data for egovernment transactions. . Computers in Human Behavior, 27(6), 2233-2242. https://doi.org/10.1016/j.chb.2011.07.002

Beldard, A., Jong, M. D., \& Streehouder, M. (2011). I trust not therefore it must be risky: Determinants of the perceived risks of discloring personal data for e-government transactions. Computers in Human Behavior, 10.

Bell, J. (2005). Doing Your Research Project . Buckingham: Open University Press.

Benbasat, I., \& Bark, H. (2007). Quo vadis TAM? Journal of the. Association for Information Systems. https://doi.org/10.17705/1jais.00126

Benbasat, I., \& Barki, H. (2007). Quo vadis TAM? J. Assoc. Inform. Syst. https://doi.org/10.17705/1jais.00126

carter, F. B. (2008). Trust and risk in e-government adoption. Journal of startegic information system, 12.

Carter, L., \& Bélanger, F. (2005). The utilization of e - government services: citizen trust, innovation and acceptance factors. Information System Journal, 15(1), 5-9.

https://doi.org/10.1111/j.1365-2575.2005.00183.x

Carter, L., \& Weerakkody, V. (2008). E-government adoption: A cultural comparison. Information Systems Frontiers, 10(4), 473-482. https://doi.org/10.1007/s10796-008-9103-6

Carter, L., Shaupp, L. C., Hobbs, J., \& Campbell, R. (2012). The role of security and trust in the adoption of online tax filing. Transforming Government: People Process and Policy, 5(4), 303-318. https://doi.org/10.1108/17506161111173568

Celene Navarrete. (2010). Trust in E-Government Transactional Services: A Study of Citizens' Perceptions in Mexico and the U.S. Proceedings of the 43rd Hawaii International Conference 
on System Sciences, 10. https://doi.org/10.1109/HICSS.2010.487

Chatfield, A., \& Alanazi, J. (2015). Collaborative governance matters to egovernment interoperability: An analysis of citizen-centric integrated interoperable e-government implementation in Saudi Arabia. International Journal of Public Administration in the Digital Age (IJPADA), 2(3), 24-44. https://doi.org/10.4018/ijpada.2015070102

Chen, C., \& Chao, W. (2011). Habitual or reasoned? Using the theory of planned behavior, technology acceptance model, and habit to examine switching intentions toward public transit Transp. Res. Part F. Traffic Psychology Behavior, 14(2), 128-137.

https://doi.org/10.1016/j.trf.2010.11.006

Chen, C., Greene, P., \& Crick., A. (1998). Chen, C., P. Greene and A. Crick. 1998. Does entrepreneurial self-efficacy distinguish entrepreneurs from managers?. Journal of Business Venturing, 13, 295-316. https://doi.org/10.1016/S0883-9026(97)00029-3

Chen, J., Jubilado, R., Capistrano, E., \& Yen, D. (2015). Factors affecting online tax filing An application of the IS Success Model and trust theory. Computers in Human Behavior, 43, 251-262. https://doi.org/10.1016/j.chb.2014.11.017

Chen, S.-Y. (2016). Green helpfulness or fun? Influences of green perceived value on the green loyalty of users and non-users of public bikes. Transport Policy.

https://doi.org/10.1016/j.tranpol.2016.01.014

Cialdini, R., Kallgren, C., \& Reno, R. (1991). A focus theory of normative conduct: A theoretical refinement and reevaluation of the role of norms in human behavior. Advances in Experimental Social Psychology, 24, 201-234.

https://doi.org/10.1016/S0065-2601(08)60330-5

Cigdem, A. M. O. (2011). Components of Trust Influencing eGovernment Adoption in Germany . IFIP International Federation for Information Processing, 12.

Conner, M., \& Armitage, C. J. (1998). Extending the theory of planned behavior: a review and avenues for further research. Journal of Applied Social Psychology, 15, 1429-1469. https://doi.org/10.1111/j.1559-1816.1998.tb01685.x

Dashti, A., Benbasat, I., \& Burton-Jones, C. A. (2010). Trust, Felt Trust, and E-Government Adoption: A Theoretical Perspective. Working Papers on Information Systems, 40.

Davis. (1989). Perceived usefulness, perceived ease of use, and user acceptance of information technology. MIS Quarterly, 13(3), 319-340. https://doi.org/10.2307/249008

Elster, J. (1989). Social norms and economic theory. Journal of Economic Perspectives, 3(4), 99-117. https://doi.org/10.1257/jep.3.4.99

Esichaikul, M. R. (2012). Factors influencing e-government adoption in Pakistan. Transforming Government: People, Process and Policy, 25.

Fink, A. (2003). The Survey Handbook. Thousand Oaks, CA: Sage.

https://doi.org/10.4135/9781412986328 
Fornell, C., \& Larcker, D. (1981). Evaluating structural equation models with unobservable variables and measurement error. Journal of Marketing Research, 18(1), 39-50. https://doi.org/10.1177/002224378101800104

Gupta, B., Dasgupta, S., \& Gupta, A. (2008). Adoption of ICT in a government organization in a developing country: An empirical study. Journal of Strategic Information Systems, 17(2), 140-154. https://doi.org/10.1016/j.jsis.2007.12.004

Hair, J., Anderson, R. T., \& Black, W. (1998). Multivariate data analysis. New Jersey: USA: Englewood Cliffs.

Hair, J., Black, W., Basin, B., \& Anderson, R. (2010). Multivariate Data Analysis. New Jercy: Pearson Prentice Hall, Upper Saddle River.

Harjer, H., \& Habib, A. (2013). Factors of entrepreneurial intention of the public civil servant: empirical evidence in the case of Tunisia. nternational Journal of Business Management and Economic Research, 672-682.

Hisham, A. M. F. (2009). Conceptualising Citizen's Trust in e-Government: Application of Q Methodology . Electronic Journal of e-Government, 16.

Hu, L., \& Bentler, P. (1999). Cutoff Criteria for Fit Indexes in Covariance Structure Analysis: Conventional Criteria Versus New Alternatives,. Structural Equation Modeling, 6(1), 1-55. https://doi.org/10.1080/10705519909540118

Kandori, M. (1992). Social norms and community enforcement. The Review of Economic Studies, 59(1), 63-80. https://doi.org/10.2307/2297925

Kautonen, T., \& Tornikoski, S. L. (2010). Influence of work history on entrepreneurial intentions in prime age and third age: a preliminary study. International Small Business Journal, 28(6), 583-601. https://doi.org/10.1177/0266242610368592

Kinicki, A., \& Krietner, R. (2009). The nature of attitudes, organizational behavior. eGraw Hill Companies Inc.

Kolvereid, L. (1996). Prediction of employment status choice intentions. Entrepreneurship Theory and Practice,fall, 21(1), 47-57. https://doi.org/10.1177/104225879602100104

Kuo, Y.-F., Wub, C.-M., \& Deng, W.-J. (2009). The relationships among service quality, perceived value, customer satisfaction, and post-purchase intention in mobile value-added services. Computers in Human Behavior, 25(4), 887-896.

https://doi.org/10.1016/j.chb.2009.03.003

Kurfali, M., Arifoglu, A., Tokdemir, G., \& Pacin, Y. (2017). Adoption of e-government services in Turkey. Computer Human Behavior, 66, 168-178.

https://doi.org/10.1016/j.chb.2016.09.041

Lallmahomed, M. Z., Lallmahomed, N., \& Lallmahomed, G. M. (2017). Factors influencing the adoption of e-Government Services in Mauritius. Telematics and Informatics. https://doi.org/10.1016/j.tele.2017.01.003 


\section{MInstitute Macrothink $_{\text {Int }}$}

Business and Economic Research ISSN 2162-4860 2019, Vol. 9, No. 2

Lemuria, C. (2008). E-government diffusion: a comparison of adoption constructs . Transforming Government: People, Process and Policy, 15.

Levy, L. A. (2014). The effect of information quality on trust in e-government systems' transformation . Transforming Government: People, Process and Policy, 26.

Liu, Y., Li, H., Kostakos, V., Goncalves, J., Hosio, S., \& Hu, F. (2014). An empirical investigation of mobile government adoption in rural China: A case study in Zhejiang province. Government Information Quarterly, 31(3), 432-442.

https://doi.org/10.1016/j.giq.2014.02.008

Ma, Q., Chan, A. H., \& Chen, K. (2016). Personal and others facors affecting acceptance of smart phone technology by elder chinese adults. Applied Ergonomics, 54, 62-71. https://doi.org/10.1016/j.apergo.2015.11.015

Meuter, M. L., Ostrom, A. L., Bitner, M. J., \& Roundtree, R. (2003). The influence of technology anxiety on consumer use and experiences with self-service technologies. Journal of Business Research, 56(11), 899-906. https://doi.org/10.1016/S0148-2963(01)00276-4

Miloševic, I., Zivkovic, D., Manasijevic, D., \& Nikolic, D. (2015). The effects of the intended behavior of students in the use of M-learning. Computers in Human Behavior, 51, 207-215. https://doi.org/10.1016/j.chb.2015.04.041

Norris, D., \& Reddick, C. (2013). Local e-government in the United States: Transformation or incremental change? . Public Administration Review, 73(1), 165-175.

https://doi.org/10.1111/j.1540-6210.2012.02647.x

Osmani, M. (2015). Examining the antecedents of public value in e-government services. . Doctoral Dissertation. Brunel University London.

Panagiotopoulos, P., Al-Debei, M., Fitzgerald, G., \& Elliman, T. (2012). A business model perspective for ICTs in public engagement. Government Information Quarterly, 29(2), 192-202. https://doi.org/10.1016/j.giq.2011.09.011

Pituch, K. A., \& Stevens, J. P. (2016). Applied multivariate statistics for the social sciences. New York: Routledge. https://doi.org/10.4324/9781315814919

Primack, B., Switzer, G., \& Dalton, M. (2007). Improving measurement of normative beliefs involving smoking among adolescents. Arch. Pediat Adolesc. Med., 161(5), 434-439. https://doi.org/10.1001/archpedi.161.5.434

Rana, N. P., Williams, M. D., Dwivedi, Y. K., \& Williams, J. (2011). Diversity and Diffusion of Theories, Models, and Theoretical Constructs in eGovernment Research. International Conference on Electronic Government, 1-12. https://doi.org/10.1007/978-3-642-22878-0_1

Rana, N., \& Dwivedi, Y. (2015). Citizen's adoption of an e-government system: Validating extended social cognitive theory (SCT). Government Information Quarterly, 32(2), 172-181. https://doi.org/10.1016/j.giq.2015.02.002

Reddick, C. (2005). Citizen interaction with e-government: From the streets to servers?. 
Government Information Quarterly, 22(1), 38-57. https://doi.org/10.1016/j.giq.2004.10.003

Rehman, M., \& Esichaikul, V. (2011). Factors influencing the adoption of e-government in Pakistan. E-Business and E-Government (ICEE), International Conference, (pp. 1-4). https://doi.org/10.1109/ICEBEG.2011.5887093

Rotter, J. (1966). Generalized expectancies for internal versus external control of reinforcemen. Psychological Monographs, 1, 80. https://doi.org/10.1037/h0092976

Shah, S. R., Khan, A. Z., \& Khalil., D. M. (2011). 'Project Management Practices In E-Government Projects: A Case Study of Electronic Government Directorate (Egd) In Pakistan. International Journal of Business and Social Science.

Shane, S. (1993). Cultural influences on national rates of innovation. Journal of Business Venturing, 59e73. https://doi.org/10.1016/0883-9026(93)90011-S

Sofia Elena Colesca. (2009). Understanding Trust in e-Government . ECONOMICS OF ENGINEERING DECISIONS, 09.

Solesvick, M. Z. (2012). Entrepreneurial motivations and intentions: investigating the role of education major. Education + Training, 55(3), 253-271.

https://doi.org/10.1108/00400911311309314

Tkachev, A., \& Kolvereid, L. (1999). Self-employment intentions among Russian students. Entrepreneurship and Regional Development, 11(3), 269-280.

https://doi.org/10.1080/089856299283209

Venkatesh, V., Thong, J., \& Xu, X. (2012). Consumer acceptance and use of information technology: extending the unified theory of acceptance and use of technology. MIS Quarterly, 36(1), 157-178. https://doi.org/10.2307/41410412

Wang, C. (2014). Antecedents and consequences of perceived value in Mobile Government continuance use: An empirical research in China. Computers in Human Behavior, 34, 140-147. https://doi.org/10.1016/j.chb.2014.01.034

Wang, L., Rau, P.-L. P., \& Salvendy, G. (2011). Older Adults Acceptance of information Technology. Educational Gerontolgy, 37(12), 1081-1099.

https://doi.org/10.1080/03601277.2010.500588

Wu, M.-Y., \& Liao, S.-C. (2013). Consumers' behavioral intention to use internet shopping: an integrated model of TAM and TRA. Journal of Statistics and Management Systems, 14(2), 375-392. https://doi.org/10.1080/09720510.2011.10701561

Xie, Q. J., Song, W., \& Shabbir, M. (2017). Predictors for e-government adoption: integrating TAM, TPB, trust and perceived risk. The Electronic Library, 35(1), 2-20.

Yordanova, D., \& Tarrazon, M. (2010). Gender differences in entrepreneurial intentions:evidence from Bulgaria. Journal of Developmental Entrepreneurship, 15(3), 245-261. https://doi.org/10.1142/S1084946710001543 


\section{Macrothink}

Business and Economic Research

ISSN 2162-4860 2019, Vol. 9, No. 2

Zhao, H., Seibert, S., \& Hills, G. (2005). The mediating role of self-efficacy in the development of entrepreneurial intentions. Journal of Applied Psychology, 90(6), 1265-1275. https://doi.org/10.1037/0021-9010.90.6.1265

Zhao, X., Sayeed, S., Cappella, J., Hornik, R., Fishbein, M., \& Ahern, R. (2006). Targeting norm-related beliefs about marijuana use in an adolescent population. Health Commun., 19(3), 187-196. https://doi.org/10.1207/s15327027hc1903_1

Zimmerman, R. (2008). Understanding the impact of personality traits on individual's turnover decision. A metal analytical model. Journal of Personnel Psychology, 61(2), 2309-348. https://doi.org/10.1111/j.1744-6570.2008.00115.x

Zulfiqar, S., Sarwar, B., Aziz, S., Chandia, K. E., \& Khan, M. K. (2018). An Analysis of Influence of Business Simulation Games on Business School Students' Attitude and Intention Toward Entrepreneurial Activities. Journal of Educational computing research, 57(1), 1-25. https://doi.org/10.1177/0735633117746746

\section{Copyright Disclaimer}

Copyright for this article is retained by the author(s), with first publication rights granted to the journal.

This is an open-access article distributed under the terms and conditions of the Creative Commons Attribution license (http://creativecommons.org/licenses/by/3.0/). 